\title{
Effect of Breed, Heterosis and Sex on Body Weight, and Glutathione Peroxidase Activities in Red Blood Cell Haemolysate and Blood Plasma at the Age of Sexual Maturity in Chickens
}

\author{
Gihan F. Shaaban ${ }^{1}$, Eissa E. Ahmed ${ }^{2}$ and Miklós Mézes ${ }^{3}$ \\ ${ }^{1}$ Department of Poultry Science, Faculty of Agriculture, Fayoum University, 63514 Fayoum, Egypt \\ ${ }^{2}$ Department of Genetics, Faculty of Agriculture, Fayoum University, 63514 Fayoum, Egypt \\ ${ }^{3}$ Department of Nutrition, Faculty of Agricultural and Environmental Sciences, Szent István University, \\ H-2103 Gödöllõ, Páter Károly u. 1., Hungary
}

\begin{abstract}
The purpose of the present study was to collect information about the possible genetic background of glutathione peroxidase (GSHPx) activity in four pure breeds and their crosses of chickens, and its correlation with body weight (BW) and studying the effect of cross-breeding and sex on GSHPx activity. Blood samples were collected from six breeds of chickens, New Hampshire (NH), Naked Neck Plymouth (NNP) and their cross $(\mathrm{NH} \times \mathrm{NNP})$, White Plymouth Rock (WPR), Naked Neck New Hampshire $(\mathrm{NNNH})$ and their cross $(\mathrm{WPR} \times \mathrm{NNNH})$ at the age of sexual maturity. GSHPx activity measured in blood plasma (BP) and red blood cell haemolysate (RBC). Results showed that there were significant differences in BW and GSHPx activities in RBC and BP among genetic groups and their crosses. NNP had the highest average BW $(1.97 \mathrm{~kg})$ and $\mathrm{NH}$ had the lowest $(1.11 \mathrm{~kg})$. WPR had the highest RBC GSHPx activity $(6.24 \mathrm{U} / \mathrm{g}$ protein) and $\mathrm{NH} \times \mathrm{NNP}$ cross had the lowest $(3.98 \mathrm{U} / \mathrm{g}$ protein). WPR $\times \mathrm{NNNH}$ had the highest BP GSHPx activity (7.23 U/g protein) and NNNH had the lowest (6.22 U/g protein). Crosses had intermediate values for BW compared to their parents. The two crosses had lower RBC GSHPx activity than their parent breeds. NH $\times$ NNP had lower BP GSHPx activity than their parent breeds while WPR $\times$ NNNH had higher values. Sex had significant effect on BW and GSHPx activity in RBC and BP, males had higher values than females for BW and BP GSHPx activity while the opposite was found in RBC GSHPx activity. Heterosis as a percentage of the midparent values of the GSHPx activities in RBC and BP also average BW has high values and affected by sex. Significant negative correlation was found between BW and RBC GSHPx activity $(-0.27 ; P<0.01)$ while, positive correlation was found between BW and BP GSHPx activity.
\end{abstract}

Key words: body weight, breed, glutathione peroxidase, heterosis, sex

J. Poult. Sci., 45: 180-185, 2008

\section{Introduction}

Recently the genetic diversity of farm animals has more importance in the animal genetics. The new trend in genetic improvement programs is to investigate the differences among the breeds of the same species. All animal species, including poultry, produce free radicals as byproducts of metabolism that could potentially damage or destroy biological molecules in cells. Superoxide dismutases, catalase, and glutathione peroxidases (GSHPx) are the most important antioxidant enzymes that destroy these free radicals before damage occurs (Özturk Ürek et al., 2001). Cellular GSHPx is a key intracellular antioxidant enzyme that contains a selenocysteine residue at its

Received: November 12, 2007, Accepted: February 18, 2008

Correspondence: Dr. M. Mézes, Department of Nutrition, Szent István University, H-2103 Gödöllõ, Hungary.

(E-mail: Mezes.Miklos@mkk.szie.hu) active site (Handy et al., 2006). The primary functions of the GSHPx iso-enzymes are to detoxify hydrogen peroxide and to convert lipid hydroperoxides to non-toxic alcohols (Jenkinson et al., 1982). The activity of blood plasma GSHPx (BP-GSHPx) has been directly linked with dietary selenium level in most of the farm animals, including poultry (Payne and Southern, 2005). Antioxidants, such as GSHPx, play an important role in maintaining bird health, productivity and reproductive characteristics (Surai, 2002).

A genetic variation in GSHPx activity has been suspected previously in sheep (Langlands et al., 1980; Atroshi and Sankari, 1981; Wiener et al., 1983; Woolliams et al., 1983), chicken (Cestnik, 1985; Cunningham et al., 1987; Shen et al., 1992; Shaaban et al., 2003, 2004), goose (Mézes et al., 1989), pig (Lingaas et al., 1992), rabbit (Mézes et al., 1994), and goat (Fidanci et al., 2001). Several studies have suggested that most of the enzyme activities in animal tissues are affected by sex. Sex differ- 
ences in GSHPx activity may be the result of differences in distribution of selenium in male and female, or they may be caused by metabolic differences (Finley and Kincaid, 1991). There are some observations about the correlation of GSHPx activity and production traits, body weight (BW), weight gain, growth rate and wool production (Atroshi and Sankari, 1981; LaVorgna and Combs, 1983; Lingaas et al., 1991; Mézes et al., 1994). Also, there are some investigations concerning to the GSHPx activity as a possible selection criteria in rabbit breeding as slight negative phenotypic correlation was found between carcass traits and GSHPx activity of red blood cell haemolysate (RBC-GSPHx) in rabbits (Virág et al., 1996). The poultry industry has a history of using breed crosses and, more recently, strain crosses, mainly to take advantage of heterosis (Fairfull, 1990). Langlands et al. (1980) reported that heterosis affect partly at the gene expression level of GSHPx activity in whole blood, the heterosis as a percentage of the mid-parent values ranged from -11.3 to 25.5. The existence of genetic variation in the concentration of GSHPx activity of different animals suggests that GSHPx activity is genetically regulated.

In present study, an attempt was made to assess the relative importance of these factors by comparing GSHPx activity in different pure breeds and cross breeds of chickens to obtain some information on the possible genetic background of GSHPx activities in RBC and BP in these breed groups, and its correlation with BW and sex at standardized conditions. The objectives of this research were to investigate the phenotypic variations in the GSHPx activities in RBC and BP in four breeds and their crosses of chickens at the age of sexual maturity.

\section{Materials and Methods}

A total of 240 blood samples (20 males $\left(\sigma^{7}\right)$ and 20 females (우) of each breed) was collected from six genetic groups of chickens, namely New Hampshire (NH) and Naked Neck Plymouth (NNP) and their cross (NH $\times$ NNP), White Plymouth Rock (WPR) and Naked Neck New Hampshire (NNNH), and their cross (WPR $\times$ $\mathrm{NNNH}$ ). The blood samples were taken at the same time from males and females at the age of sexual maturity. All birds were clinically healthy and kept in the same environmental conditions and given the same diet. Blood samples were collected by venipuncture into tubes containing $200 \mu \mathrm{L}$ EDTA $(0.2 \mathrm{~mol} / \mathrm{L})$ as anticoagulant. Freshly collected blood samples were centrifuged $(15 \mathrm{~min}$, $2,500 \mathrm{rpm})$, plasma was removed and stored frozen $(-20$ $\left.{ }^{\circ} \mathrm{C}\right)$ until analysed. Erythrocytes was haemolysed with nine-fold of their volume of redistilled water and by freezing $\left(-20^{\circ} \mathrm{C}, 24\right.$ hours $)$ and thawing $\left(37^{\circ} \mathrm{C}, 30 \mathrm{~min}\right)$.

GSHPx activity was measured using reduced glutathione and cumene-hydroperoxide as co-substrates (Matkovics et al., 1988). The enzyme activity was expressed in units reflecting the oxidation of reduced glutathione in nmoles per minute at $25^{\circ} \mathrm{C}$ and was related to the protein content. Protein content of BP and RBCs were determined using biuret method (Weichselbaum, 1946).

Data of body weight, GSHPx activity in BP and RBC were analysed using two-ways ANOVA, according to the following model: $Y_{\mathrm{ijk}}=\mathrm{M}+\mathrm{G}_{\mathrm{i}}+\mathrm{S}_{\mathrm{j}}+(\mathrm{GS})_{\mathrm{ij}}+\mathrm{e}_{\mathrm{ijk}}$. where: $M=$ the common mean, $G_{i}=$ the effect of the $i^{\text {th }}$ breed group; $\mathrm{S}_{\mathrm{j}}=$ the effect of the $\mathrm{j}^{\text {th }}$ sex: $(\mathrm{GS})_{\mathrm{ij}}=$ the effect of interaction between the $i^{\text {th }}$ breed group and the $j^{\text {th }}$ sex; $e_{i j k}$ $=$ random error term, using the GLM procedure of SPSS program (SPSS, 1999). Means were compared for main effects and their interaction by Duncan's multiple range test (Duncan, 1955), when significant $\mathrm{F}$ values were obtained $(P<0.05)$. Heterosis was calculated as a percentage of the midparent values. Correlation analyses were performed by using the CORR procedure from SPSS program (SPSS, 1999) and Spearman correlation coefficient was used.

\section{Results}

\section{Phenotypic Variations of Body Weight}

Concerning breed effect, significant differences were found among the breeds showing the highest average BW in NNP $(1.97 \mathrm{~kg})$ and the lowest in NH breed $(1.11 \mathrm{~kg})$. $\mathrm{NH} \times \mathrm{NNP}$ cross had higher BW than their parent NH and lower BW than their parent NNP, also the WPR $\times$ NNNH cross had higher BW than their parent NNNH and lower BW than their parent WPR as shown in Table 1. Sex had also significant influence on BW, males having higher values than females (Table 1). Breed and sex interaction showed that males had significantly higher BW than females in all breed groups as shown in Table 2.

\section{Phenotypic Variations of GSHPX Activity in Red Blood Cell Haemolysate}

Regarding the breed effect, WPR had highest activity (6.24 U/g protein), and $\mathrm{NH}$ had the lowest $(4.70 \mathrm{U} / \mathrm{g}$ protein). $\mathrm{NH} \times \mathrm{NNP}$ cross had lower activity $(3.98 \mathrm{U} / \mathrm{g}$ protein) than their parents NH and NNP (4.70 and 4.93 $\mathrm{U} / \mathrm{g}$ protein), also WPR $\times$ NNNH cross had lower activity $(4.83 \mathrm{U} / \mathrm{g}$ protein) than their parents WPR and NNNH (6.24 and 5.38 U/g protein) as shown in Table 1. Sex had, also significant influence on GSHPx activity in RBC, females having higher enzyme activity than males (Table 1). Regarding breed and sex interaction, females had higher RBC-GSHPx activity than males in all breed groups except for NNP breed as shown in Table 2.

Phenotypic Variations of GSHPx Activity in Blood Plasma

Concerning breed effect, significant differences of GSHPx activity were found among the breeds showing the highest enzyme activity in WPR (7.08 U/g protein) and the lowest in $\mathrm{NNNH}$ breed (6.22 $\mathrm{U} / \mathrm{g}$ protein). $\mathrm{NH} \times$ NNP cross had lower insignificant activity $(6.87 \mathrm{U} / \mathrm{g}$ protein) than their parents NH and NNP (7.00 and $6.90 \mathrm{U} / \mathrm{g}$ protein) while, the WPR $\times$ NNNH cross had significant higher activity (7.23 $\mathrm{U} / \mathrm{g}$ protein) than their parents WPR and $\mathrm{NNNH}$ breeds ( 7.08 and $6.22 \mathrm{U} / \mathrm{g}$ protein) as shown in Table 1. Sex had also significant influence on BPGSHPx activity, males having higher GSHPx activity 
Table 1. Body weight (BW), GSHPx activity in red blood cells (RBC) and blood plasma (BP) in different breed and sex groups of chickens (means \pm SEM)

\begin{tabular}{|c|c|c|c|}
\hline \multirow{2}{*}{ Breed } & BW & $\mathrm{RBCs}$ & $\mathrm{BP}$ \\
\hline & $\mathrm{kg}$ & \multicolumn{2}{|c|}{ GSHP $\times$ activity $(\mathrm{U} / \mathrm{g}$ protein content $)$} \\
\hline \multicolumn{4}{|c|}{ Breed effect } \\
\hline NH & $1.11 \pm 0.05^{\mathrm{d}}$ & $4.70 \pm 0.33^{\mathrm{c}}$ & $7.00 \pm 0.41^{\mathrm{ab}}$ \\
\hline NNP & $1.79 \pm 0.08^{\mathrm{a}}$ & $4.93 \pm 0.24^{\mathrm{b}}$ & $6.90 \pm 0.24^{\mathrm{ab}}$ \\
\hline $\mathrm{NHt} \times \mathrm{NNP}$ & $1.46 \pm 0.05^{\mathrm{b}}$ & $3.98 \pm 0.23^{c}$ & $6.87 \pm 0.28^{\mathrm{ab}}$ \\
\hline WPR & $1.53 \pm 0.06^{\mathrm{b}}$ & $6.24 \pm 0.54^{\mathrm{a}}$ & $7.08 \pm 0.31^{\mathrm{ab}}$ \\
\hline NNNH & $1.26 \pm 0.05^{\mathrm{c}}$ & $5.38 \pm 0.39^{\mathrm{ab}}$ & $6.22 \pm 0.37^{\mathrm{b}}$ \\
\hline $\mathrm{WPR} \times \mathrm{NNNH}$ & $1.47 \pm 0.07^{\mathrm{b}}$ & $4.83 \pm 0.27^{\mathrm{b}}$ & $7.23 \pm 0.33^{\mathrm{a}}$ \\
\hline \multicolumn{4}{|c|}{ Sex effect } \\
\hline$\sigma^{7}$ & $1.61 \pm 0.04^{\mathrm{a}}$ & $4.32 \pm 0.32^{\mathrm{b}}$ & $7.35 \pm 0.27^{\mathrm{a}}$ \\
\hline 우 & $1.22 \pm 0.03^{\mathrm{b}}$ & $5.62 \pm 0.35^{\mathrm{a}}$ & $6.43 \pm 0.30^{\mathrm{b}}$ \\
\hline
\end{tabular}

${ }^{\mathrm{a}, \mathrm{b}}$ Different letters in each column means significant difference $(P<0.05)$.

Table 2. Breed by sex interactions of body weight (BW), GSHPx activity in red blood cells (RBC) and blood plasma (BP) in chickens (means \pm SEM)

\begin{tabular}{|c|c|c|c|c|}
\hline Breed & Sex & $\begin{array}{l}\text { BW } \\
(\mathrm{kg})\end{array}$ & GSHPx (U/g protein content) & $\begin{array}{c}\mathrm{BP} \\
\text { in content) }\end{array}$ \\
\hline \multirow[t]{2}{*}{$\mathrm{NH}$} & $\sigma^{7}$ & $1.26 \pm 0.06^{\mathrm{ef}}$ & $4.43 \pm 0.56^{\mathrm{cd}}$ & $6.95 \pm 0.47^{\mathrm{a}}$ \\
\hline & 우 & $0.95 \pm 0.05^{\mathrm{g}}$ & $4.99 \pm 0.34^{\mathrm{c}}$ & $7.04 \pm 0.71^{\mathrm{a}}$ \\
\hline \multirow[t]{2}{*}{ NNP } & $\sigma^{\pi}$ & $1.99 \pm 0.07^{\mathrm{a}}$ & $5.10 \pm 0.38^{\mathrm{c}}$ & $7.22 \pm 0.11^{\mathrm{a}}$ \\
\hline & 우 & $1.46 \pm 0.06^{\mathrm{cd}}$ & $4.66 \pm 0.28^{\mathrm{cd}}$ & $6.38 \pm 0.52^{\mathrm{ab}}$ \\
\hline \multirow[t]{2}{*}{$\mathrm{NH} \times \mathrm{NNP}$} & $\sigma^{T}$ & $1.62 \pm 0.07^{\mathrm{c}}$ & $3.60 \pm 0.36^{\mathrm{d}}$ & $7.49 \pm 0.29^{\mathrm{a}}$ \\
\hline & 우 & $1.33 \pm 0.04^{\mathrm{de}}$ & $4.28 \pm 0.28^{\mathrm{cd}}$ & $6.38 \pm 0.40^{\mathrm{ab}}$ \\
\hline \multirow[t]{2}{*}{ WPR } & $\sigma^{T}$ & $1.78 \pm 0.03^{\mathrm{b}}$ & $4.27 \pm 0.49^{\mathrm{cd}}$ & $7.45 \pm 0.49^{\mathrm{a}}$ \\
\hline & 우 & $1.31 \pm 0.04^{\mathrm{de}}$ & $7.94 \pm 0.48^{\mathrm{a}}$ & $6.76 \pm 0.34^{\mathrm{ab}}$ \\
\hline \multirow[t]{2}{*}{$\mathrm{NNNH}$} & $0^{T}$ & $1.41 \pm 0.06^{\mathrm{de}}$ & $4.21 \pm 0.16^{\mathrm{cd}}$ & $7.16 \pm 0.52^{\mathrm{a}}$ \\
\hline & 우 & $1.10 \pm 0.03^{\mathrm{fg}}$ & $6.66 \pm 0.55^{\mathrm{b}}$ & $5.18 \pm 0.28^{\mathrm{b}}$ \\
\hline \multirow[t]{2}{*}{$\mathrm{WPR} \times \mathrm{NNNH}$} & $\sigma^{T}$ & $1.79 \pm 0.04^{\mathrm{b}}$ & $4.30 \pm 0.30^{\mathrm{cd}}$ & $7.80 \pm 0.44^{\mathrm{a}}$ \\
\hline & 우 & $1.25 \pm 0.07^{\mathrm{ef}}$ & $5.20 \pm 0.41^{\mathrm{c}}$ & $6.83 \pm 0.45^{\mathrm{ab}}$ \\
\hline
\end{tabular}

${ }^{\mathrm{a}, \mathrm{b}}$ Different letters in the same column means significant difference $(P<0.05)$.

than females (Table 1). Breed and sex interaction showed that males had higher BP-GSHPx activity than females in all breed groups except for NH breed (Table 2).

\section{Heterosis Effect}

Means of heterosis estimates percentage (as a percentage of the midparent values) of $\mathrm{NH} \times \mathrm{NNP}$ and WPR $\times$ NNNH crosses for GSHPx activities in BP and RBC, and $\mathrm{BW}$ are presented in Table 3. Heterosis estimates for GSHPx activities in BP and RBC, and BW in males, females and both sexes indicated that males had higher percentages than females for GSHPx activities in BP and $\mathrm{RBC}$ in $\mathrm{NH} \times \mathrm{NNP}$ cross, while the opposite was found for WPR $\times$ NNNH cross as shown in Table 3 . All heterosis percentages for RBC-GSHPx activity were negative and had high values except for males of WPR $\times$ NNNH cross. Heterosis estimates for BP-GSHPx activity were negative for $\mathrm{NH} \times \mathrm{NNP}$ cross, while the opposite was found for WPR $\times$ NNNH cross. All heterosis estimates for BW were positive and had high percentages except for males of NH $\times$ NNP cross (Table 3 ).

Phenotypic Correlation between GSHPx Activities in Red Blood Cells Haemolysate and Blood Plasma with Body Weight

Regarding the breed effect of GSHPx activity, negative correlations were found for all breeds except for NNP. Significant negative correlations were found between BW and RBC-GSHPx activity for WPR and NNNH $(-0.68$ and $-0.67 ; P<0.01)$ as shown in Table 4 . The overall of all observations showed significant negative correlation between BW and RBC-GSHPx activity (Table 4).

The phenotypic correlations between BW and BPGSHPx activity of the various breeds had different values (Table 4). Positive correlations were found for all breeds except for NNP. The overall of all observations showed 
Table 3. Mean estimated heterosis effect computed as a percentage of the mid-parent values of $N H \times N N P$ and $W P R \times N N N H$ crosses of GSHPx activity in red blood cells (RBC) and blood plasma (BP), and body weight (BW)

\begin{tabular}{|c|c|c|c|c|}
\hline \multirow{2}{*}{ Breed } & \multirow{2}{*}{ Sex } & \multicolumn{3}{|c|}{ Heterosis $\%$} \\
\hline & & $\mathrm{RBC}$ & $\mathrm{BP}$ & BW \\
\hline \multirow[t]{3}{*}{$\mathrm{NHt} \times \mathrm{NNP}$} & $\sigma^{\pi}$ & -24.45 & -5.72 & -0.38 \\
\hline & 우 & -11.30 & -4.92 & +10.37 \\
\hline & $\left(0^{7}+\right.$ 우 $)$ & -17.34 & -1.15 & +0.69 \\
\hline \multirow[t]{3}{*}{$\mathrm{WPR} \times \mathrm{NNNH}$} & $0^{x}$ & +1.42 & +6.78 & +12.23 \\
\hline & 우 & -28.77 & +14.41 & +3.73 \\
\hline & $\left(0^{7}+\right.$ 우 $)$ & -16.87 & +8.73 & +5.38 \\
\hline
\end{tabular}

Table 4. Phenotypic correlation between GSHPx activity in red blood cells (RBC) and blood plasma (BP), and body weight (BW)

\begin{tabular}{lcc}
\hline \multicolumn{1}{c}{ Breed } & RBC & BP \\
\hline NH & -0.35 & -0.07 \\
NNP & 0.04 & 0.08 \\
NH $\times$ NNP & -0.24 & 0.16 \\
WPR & $-0.68^{* *}$ & 0.08 \\
NNNH & $-0.67^{* *}$ & 0.40 \\
WPR $\times$ NNNH & -0.27 & 0.08 \\
\hline Overall mean & $-0.27^{* *}$ & 0.12 \\
\hline
\end{tabular}

** Correlation is significant at $P<0.01$ level.

that, positive correlation was found between BW and BP-GSHPx activity as shown in Table 4.

Phenotypic Correlation between GSHPx Activity in Blood Plasma and Red Blood Cell Haemolysate

Significant positive correlation between GSHPx activity in $\mathrm{BP}$ and $\mathrm{RBC}$ was found $(0.35 ; P<0.01)$.

\section{Discussion}

Several studies pointed out that the expression of that antioxidant enzyme, GSHPx, varies according to genetic background, sex, age, physiological status, site of organs and diet (Lingaas et al., 1991; Mote et al., 1991; Nijhoff and Peters, 1992; Egaas et al., 1995). Especially, genetic background and sex differences in antioxidant defence mechanism are of importance from many points of view such as cancer development, toxicology, and health of animals (Lingaas et al., 1991; Van Lieshout and Peters, 1998; Jang et al., 2001). The existence of genetic variation in the GSHPx activity in blood, liver and RBC of different animals suggests that GSHPx activity, beside other factors (Erdélyi et al., 2001), is genetically regulated.

Environment and diet was the same for all breeds. This suggests that the observed differences among them are likely genetic ones. Thus, the results appear to support those of Langlands et al. (1980), Woolliams et al. (1983) and Fidanci et al. (2001), who reported breed differences in the GSHPx activity in the whole blood of sheep, cattle and goat. Also the present results are in agreement with those reported by Cestnik (1985) who found significant differences in the GSHPx in whole blood between two breeds of chickens (Rhode Island Red and Prelux-Bro) during embryonic development, day-old age and at the period of egg production. Langlands et al. (1980) reported that heterosis affects partly at the gene expression level of whole blood GSHPx activity, the heterosis as a percentage of the mid-parent values ranged from -11.3 to 25.5, which is in agreement of present results.

Few previous works has been done on the correlation between production traits and GSHPx activity. It is concluded that, the correlations depends on the species and tissue. Also, present results show that, the correlations are influenced by breeds and tissues.

Negative correlations between BW and RBC-GSHPx activity which were obtained in present experiment are similar to the results reported by Atroshi and Sankari (1981) in sheep, LaVronga and Combs (1982) in chicken, Lingaas et al. (1991) in pig, Mézes et al. (1994) and Virág et al. (1996) in rabbit. The significant negative correlation between BW and RBC-GSHPx activity may represent an adaptation mechanism to relatively low selenium intake particularly in animals with higher growth rate (Atroshi and Sankari, 1981) but further research is needed to prove that hypothesis. Also further studies are needed to investigate the other antioxidant enzymes and its correlation with production traits. Contrary to RBC, BP-GSHPx activity showed positive correlation with $\mathrm{BW}$ in most of the breeds investigated. That difference probably caused by the different origin of the enzyme molecule. RBCGSHPx synthesise in the red blood cells while BP-GSHPx in the kidney tubular cells and it depends on the actual selenium supply less than the RBC-GSHPx, but the enzyme synthesis, and consequently the BP-GSHPx activity depends on the integrity of kidney tubular epithelial cells (Avissar et al., 1994). Phenotypic correlation between GSHPx activity in BP and RBC is not reported before, 
present data indicated that, the measure of the enzyme activity in one tissue could be used as a good indicator to the GSHPx activity in other tissues based one the high correlation values which obtained in present results but further research need to prove this hypothesis.

In conclusion, phenotypic variation in the GSHPx activity may have given an opportunity for selection among breeds. Based on, heterosis percentages, cross-breeding plays a part in the expression of enzyme activity. Significant negative correlation between body weight and RBCGSHPx activity may represent an adaptation to low selenium intake, so when selenium deficiency diseases such as nutritional muscular degeneration are common. Further research is needed to establish if the low enzyme activity really represent an adaptation to low selenium intake. It would be important to pinpoint the biochemical difference, if alternative non-selenium dependent pathways of peroxide detoxification occur in the low enzyme activity. Such information would be important in the search for the possibility of genetically selecting birds and animals resistant to selenium deficiency.

\section{References}

Atroshi F and Sankari S. Variation of erythrocyte glutathione peroxidase activity in Finn sheep. Research in Veterinary Science, 31: 267-271. 1981.

Avissar N, Ornt DB, Yagil Y, Horowitz S, Watkins RH, Kerl EA, Takahashi K, Palmer IS and Cohen HJ. Effect of renal failure on blood plasma glutathione peroxidase activity in dialysed patients. American Journal of Physiology, 266: C 367-C372. 1994.

Cestnik V. Glutathione peroxidase activity in embryonal development of chicken (In Russian). Veterinarstvo, 22: 187-193. 1985.

Cunningham DL, Combs GF, Saroka JA and LaVorgna MW. Response to divergent selection for early growth of chickens fed a diet deficient in selenium. Poultry Science, 66: 209214. 1987.

Duncan DB. The multiple range and multiple F test. Biometrics, 11: 1-42. 1955.

Egaas E, Falls FG and Dauterman WC. A study of gender, strain and age differences in mouse liver glutathione-S-transferase. Comparative Biochemistry and Physiology, 110C: 35-40. 1995.

Erdélyi M, Mézes M and Virág Gy. Environmental induction models for the investigation of activity changes in glutathione peroxidase, a crucial factor of the antioxidant defense. Acta Physiologica Hungarica, 88: 117-124. 2001.

Fairfull RW. Heterosis. In: Poultry Breeding and Genetics (Crawford RD ed.) pp. 913-933. Elsevier, Amsterdam, 1990.

Fidanci UR, Turgay F, Zengin S, Kargin F, Celik S and Tasdemir U. The effect of genotype on the antioxidative metabolism in Angora goats. Turkish Journal of Veterinary and Animal Science, 25: 975-981. 2001.

Finley JW and Kincaid RL. Effect of sex and time of sampling on selenium and glutathione peroxidase activity in tissues of mature rats. Biological Trace Element Research, 29: 181191. 1991.

Handy DE, Hang G, Scolaro J, Metes N, Razaq N, Yang Y and
Loscalzo J. Aminoglycosides decrease glutathione peroxidase-1 activity by interfering with selenocysteine incorporation. Journal of Biological Chemistry, 281: 3382-3388. 2006.

Jang IE, Kabryong C and Jungsik C. Effect of age and strain on small intestinal and hepatic antioxidant defence enzymes in Wistar and Fisher 344 rats. Mechanism of Ageing and Development, 122: 561-570. 2001.

Jenkinson SG, Lawrence RA, Burk RF and Williams DM. Effects of copper deficiency on the activity of the selenoenzyme glutathione peroxidase on excretion and tissue retention of ${ }^{75} \mathrm{SeO}_{3}$. Journal of Nutrition, 112: 197-204. 1982.

Langlands JP, Bowles JE, Donald GE, Chang TS, Evans R, Hearnshaw H and Post TB. Genotype as a source of variation in selenium concentration and glutathione peroxidase activity of whole blood from grazing sheep and cattle. Australian Journal of Agricultural Research, 31: 839-848. 1980.

LaVorgna MW and Combs GF. Evidence of a hereditary factor affecting the chick's response to uncomplicated selenium deficiency. Poultry Science, 62: 164-168. 1983.

Lingaas F, Brun E and Froslie A. Estimates of heritability for selenium and glutathione peroxidase levels in pigs. Journal of Animal Breeding and Genetics, 108: 48-53. 1991.

Lingaas F, Brun E, Havre G, Froslie A, Aarskaug T and Vangen O. Biochemical blood parameters in pigs. 1. Repeatability and effects of breed, litter number and sampling time. Journal of Animal Breeding and Genetics, 109: 221-230. 1992.

Matkovics B, Szabó L and Varga SI. Determination of enzyme activity in lipid peroxidation and glutathione pathways (In Hungarian). Laboratóriumi Diagnosztika, 15: 248-250. 1988.

Mézes M, Szalay I and Vas E. Glutathione metabolism enzymes as possible markers for goose liver selection. Proceedings of the International Symposium on Current Problems of Avian Genetics, Smolenice, pp.114-118. 1989.

Mézes M, Eiben Cs and Virág Gy. Determination of glutathione peroxidase enzyme activity in blood plasma, red blood cells and liver of rabbits. Correlation between the enzyme activity and some production traits (In Hungarian). Proceedings of the 6th Rabbit Breeding Day, PATE, Kaposvár, pp. 121126. 1994.

Mote PL, Grizzle JM, Walford RL. and Spindler SR. Influence of age and caloric restriction on expression of hepatic genes for xenobiotics and oxygen metabolising enzymes in the mouse. Journal of Geronotology, 3: 95-100. 1991.

Nijhoff WA and Peters WHM. Induction of rats hepatic and intestinal glutathione-S-transferases by dietary butyrated hydroxyanisole. Biochemical Pharmacology, 3: 596-600. 1992.

Özturk Ürek R, Bozkaya LA and Tarhan L. The effects of some antioxidant vitamin- and trace element-supplemented diets on activities of SOD, CAT, GSH-Px, and LPO levels in chicken tissues. Cell Biochemistry and Function, 19: 125132. 2001.

Payne RL and Southern LL. Changes in glutathione peroxidase and tissue selenium concentrations of broilers after consuming a diet adequate in selenium. Poultry Science, 84: 12681276. 2005.

Shaaban G, Mézes M and Hidas A. Phenotypic variation of glutathione peroxidase activity in different genotypes of different age groups of chicken and its correlation with some 
production traits. Archiv für Geflügelkunde, 67: 217-224. 2003.

Shaaban G, Mézes M and Hidas A. Phenotypic variation in the activities of glutathione peroxidase and their correlation with some production traits in two chicken breeds and their crosses. Archiv für Geflügelkunde, 68: 211-217. 2004.

Shen Y, Engberg R and Jakobsen K. On the requirement of vitamin $\mathrm{E}$ in fast and slow growing chickens experiments with broiler and leghorn type chickens. Journal of Animal Physiology and Animal Nutrition 67: 113-122. 1992.

SPSS for Windows Version 9, SPSS Inc., 1999.

Surai PF. Natural antioxidants in avian nutrition and reproduction. Nottingham University Press, Nottingham, pp. 1-26. 2002.

Van Lieshout EM. and Peters WH. Age and gender dependent levels of glutathione and glutathione-S-transferase in human lymphocytes. Carcinogenesis, 10: 1873-1875. 1998.

Virág Gy, Mézes M, Szendrõ Zs, Romvári R, Radnai I and
Bíróné E. Moderate phenotypic relationships between glutathione peroxidase activity and carcass traits in rabbit could be partially determined by genetic effect. Proceedings of the 6th World Rabbit Congress, Toulouse, Volume 2, 381-384. 1996.

Weichselbaum TE. An accurate and rapid method for the determination of protein in small amounts of serum and plasma. American Journal of Clinical Pathology, 16: 40-43. 1946.

Wiener G, Woolliams JA and Vagg MG. Selenium concentration in the blood and wool and glutathione peroxidase activity in the blood of three breeds of sheep. Research in Veterinary Science, 34: 265-266. 1983.

Woolliams JA, Wiener G, Anderson PH and McMurray $\mathrm{CH}$. Variation in the activity of glutathione peroxidase and superoxide dismutase and the concentration of copper in the blood in various breed crosses of sheep. Research in Veterinary Science, 34: 253-256. 1983. 